JURNAL AL BAYAN: JURNAL JURUSAN PENDIDIKAN BAHASA ARAB

\title{
The Effectiveness of Grammatical Hunting Game Method towards Students' Arabic Learning Motivation
}

\author{
Muhammad Jafar Shodiq ${ }^{1}$, Zaimatuz Zakiyah ${ }^{2}$, Zainal Abidin Hajib ${ }^{3}$ \\ ${ }^{1}$ Master of Arabic Education Study Program Universitas Islam Negeri Sunan Kalijaga Yogyakarta, \\ Indonesia \\ ${ }^{2}$ Master of Arabic Education Study Program Universitas Islam Negeri Sunan Kalijaga Yogyakarta, \\ Indonesia \\ ${ }^{3}$ Arabic and Communication Study Program Universiti Sains Islam Malaysia, Malaysia
}

\section{Article History:}

Received : January 24, 2021

Revised : February 23, 2021

Accepted : March 25, 2021

Published : June 01, 2021

\section{Keywords:}

Arabic learning; Grammatical

Hunting; Language games; Method;

Motivation; Qawā'id

*Correspondence Address:

muhammad.shodiq@uin-suka.ac.id

\begin{abstract}
This experimental research was motivated by the low Arabic learning motivation in class VIII MTsN 9 Bantul which was caused by the use of monotonous learning methods. This study aims to find out students' Arabic learning motivation after the application of Grammatical Hunting language educational game method and to compare the Arabic learning motivation of the experimental class and the control class. This study used a quasi-experimental research type. The sample of this research was students of class VIII B and VIII C of MTsN 9 Bantul Yogyakarta consisting of 60 students. Data were collected through observation, interviews, questionnaires, and documentation. The results of this study indicated that: 1) The student's Arabic learning motivation increased after the application of Grammatical Hunting language educational game method based on the results of the paired sample t-test with a significance value of $0.000<$ 0.05 , Ha was accepted. 2) There was a significant difference in the learning motivation of the experimental class and the control class, based on the results of the independent sample t-test with a significance value of $2.042 \geq 2.001$, Ha was accepted. This method could increase students' motivation to learn Arabic. This study contributed to the use of varied learning methods, so that qawā'id learning would become an enjoyable learning.
\end{abstract}

\section{Introduction}

Qawa'id is the most important knowledge among the Arabic linguistics ${ }^{1}$ because qawa'id can help students in understanding the sources of Islamic teachings ${ }^{2}$ and Arabic literature $^{3}$ which related to Islam. ${ }^{4}$ However, the students assume that qawa'id is a

\footnotetext{
${ }^{1}$ Syaikh Musthafa Al-Ghulayaini, Jāmi 'u Ad-Durūs al-'Arabiyah (Beirut-Lebanon: Darul Bayan, 2008), 7.

2 Danial Hilmi, "Ta'lim Al-Qawa'id Al-Nahwiyah 'Ala Asas Madkhal Al-Tanwim AlMaghnathisi," Arabi : Journal of Arabic Studies 2, no. 1 (August 6, 2017): 54-66.

${ }^{3}$ Rini Rini, "Ushul al-Nahwi al-Arabi : Kajian Tentang Landasan Ilmu Nahwu," Arabiyatuna: Jurnal Bahasa Arab 3, no. 1 (May 14, 2019): 145-162.
} 
difficult lesson ${ }^{5}$. It finally causes the student to be less interested, less enthusiastic, and bored to participate in the lesson. ${ }^{6}$ They find many difficulties in the learning process is because of low motivation ${ }^{7}$. Moreover, motivation is very important ${ }^{8}$ in the second language learning process. ${ }^{9}$ One of the factors of student's Arabic learning motivation is the learning method. ${ }^{10}$ The use of appropriate learning methods ${ }^{11}$ can help students to understand $^{12}$ and overcome difficulties in understanding qawä'id. ${ }^{13}$ Meanwhile, qawā'id learning in this school is only presented using the lecture method especially in class VIII. As a teacher-centered learning method, ${ }^{14}$ this method will be more enjoyable when it is combined with other learning methods, models, or techniques to prevent students from getting bored. ${ }^{15}$ Djamarah suggested that one of the learning methods that can be applied to increase student learning motivation is games. ${ }^{16}$

Language games are another learning method that is effective ${ }^{17}$ because it can provide benefits to academic achievement ${ }^{18}$ and class dinamic. ${ }^{19}$ Other researchers stated

\footnotetext{
4 "Peraturan Menteri Agama Republik Indonesia No. 000912 Tentang Kurikulum Madrasah 2013 Mata Pelajaran Pendidikan Agama Islam Dan Bahasa Arab,” 2013.

5 Mokhammad Miftakhul Huda et al., "Improvement Of Nahwu And Sharaf Learning Using Amtsilati Method," Ijaz Arabi Journal of Arabic Learning 3, no. 1 (April 5, 2020).

${ }^{6}$ Maman Abdurrahman et al., "Tantangan Guru Bahasa Arab Madrasah Aliyah Dalam Perspektif Kompetensi Pedagogik Dan Profesional," Arabiyat : Jurnal Pendidikan Bahasa Arab dan Kebahasaaraban 2, no. 1 (July 1, 2015): 43-58.

7 Achmad Tito Rusady, “دو افع الطلاب في تعلم اللغة العربية و دور المعلم في ترقيتها., Izdihar : Journal of Arabic Language Teaching, Linguistics, and Literature 1, no. 1 (September 7, 2018): 65-78.

8 Adaninggar Septi Subekti. "L2 Motivational Self System and L2 Achievement: A Study of Indonesian EAP Learners”. Indonesian Journal of Applied Linguistics 8, no. 1 (2018): 57-67.

${ }^{9}$ Rebecca Oxford and Jill Shearin, "Language Learning Motivation: Expanding the Theoretical Framework," The Modern Language Journal 78, no. 1 (1994): 12-28.

${ }^{10}$ Asep Muhammad Saepul Islam, "Faktor Demotivasi Pembelajaran Bahasa Arab Dalam Perspektif Siswa Madrasah," Arabiyat : Jurnal Pendidikan Bahasa Arab dan Kebahasaaraban 2, no. 1 (July 1, 2015): $1-16$.

${ }^{11}$ M. Asy’ari M. Asy’ari, "Method Of Nahwu In Arabic Learning," لسـنانـ (LISANUNA): Jurnal Ilmu Bahasa Arab dan Pembelajarannya 10, no. 1 (August 27, 2020): 70-92.

12 Mirosław Pawlak, "Grammar Learning Strategies as a Key to Mastering Second Language Grammar: A Research Agenda," Language Teaching 53, no. 3 (July 2020): 358-370.

13 Ubaid Ridlo, "Model Pembelajaran Bahasa Arab Materi Al-Qawa'id al-Nahwiyyah," $A l$ Ma 'rifah: Jurnal Budaya, Bahasa, dan Sastra Arab 12, no. 2 (October 2, 2015): 46-57.

${ }^{14}$ Namaziandost Ehsan, Shatalebi Vida, and Nasri Mehdi."The Impact of Cooperative Learning on Developing Speaking Ability and Motivation Toward Learning English."Journal of Language and Education 5, no. 3 (19) (2019).

${ }^{15}$ Nida Adilah, "Perbedaan Hasil Belajar IPA melalui Penerapan Metode Mind Map dengan Metode Ceramah," Indonesian Journal of Primary Education 1, no. 1 (June 17, 2017): 98-103.

${ }^{16}$ Syaiful Bahri Djamarah, Psikologi Pendidikan (Jakarta: Rineka Cipta, 2011), 173.

${ }^{17}$ Moh In'ami and Putri Zunita Shara, "Wasilah al Lu'bah al Lughowiyah Broken Square Wa Snow Balling Fii Ta'lim al Lughoh al 'Arabiyyah Li Tarqiyah Maharoh al Qiroah," Jurnal Al Bayan: Jurnal Jurusan Pendidikan Bahasa Arab 10, no. 2 (December 20, 2018): 224-239.

${ }^{18}$ Arif Widodo, "Al-Lu'bah al-Lughawiyyah al-Namudzajiyyah Fi Ta'lim al-Kitabah,” Jurnal Al Bayan: Jurnal Jurusan Pendidikan Bahasa Arab 11, no. 1 (June 1, 2019): 111-132.
} 
that language game is interesting ${ }^{20}$ because students enjoyed ${ }^{21,22}$ and no longer felt bored in doing the Arabic learning activities. ${ }^{23}$ From these several previous research, it can be seen that research that discusses language games is applied in language learning to increase students' language skills and vocabularies. There is a research that examines learning motivation, but it is intended for students in an university. ${ }^{24}$ Therefore, this research discusses the effect of language educational game method in qawa'id learning on students' motivation to learn Arabic.

Among the game methods that are effective to be applied in qawā'id learning is Grammatical Hunting which is a language educational game method that aims to find grammatical structures in boxes or tables. This method also allows a student to develop grammar through imagination and combine one word with another. ${ }^{25}$ Asyrofi wrote in his book about the procedures of this language educational game. First, the teacher made a list and determines a theme. After that, the students were divided into groups ${ }^{26}$ and each group tried to answer the game challenges. Then, the group hunt for words by circling the words horizontally, vertically, or in a cross. ${ }^{27}$

The researchers conducted experimental research by applying the Grammatical Hunting language educational game method in Arabic learning, especially qawä'id learning to find wheter student's Arabic learning motivation improve after implementing

19 Ahmad Zubaidi, "Development Of Mahârah Al-Istimâ' Test Instrument For Electronic Based Arabic Student Using The Kahoot! Application," Arabiyat: Jurnal Pendidikan Bahasa Arab dan Kebahasaaraban 7, no. 1 (June 4, 2020): 61-77.

${ }^{20}$ Pabbuleti Prasad, "Language Games - A Games Better Method of Learning Vocabularies" (Presented at the International Multidisciplinary Conference on "Knowledge Sharing, Technological Advancements \& Sustainable Development" IMC2K18, IJREAM: International Journal for Research in Engineering Application \& Management, n.d.), 338-341.

21 Endang Sulistianingsih, Rizka Febriani, and Jcs Pradjarto, "The Effect of Interactive Board Games (IBG) on Vocabulary Achievement," Langkawi: Journal of The Association for Arabic and English 5, no. 2 (December 27, 2019): 127-139.

${ }^{22}$ Sarah N. Latuconsina, "Efektivitas Permainan Bahasa Arab Dalam Meningkatkan Kemampuan Membaca Mahasiswa Program Studi Pendidikan Bahasa Arab," Arabi: Journal of Arabic Studies 3, no. 2 (December 31, 2018): 145-156.

${ }^{23}$ Asnul Uliyah and Zakiyah Isnawati, "Metode Permainan Edukatif Dalam Pembelajaran Bahasa Arab," Shaut al Arabiyyah 7, no. 1 (June 27, 2019): 31-43.

${ }^{24}$ Muassomah Muassomah and Ma'rifatul Munjiah, "Learning Qawaid Through Language Game Adlif Kalimatan for Students of Arabic Language and Literature at UIN Maulana Malik Ibrahim Malang," ALSINATUNA 5, no. 1 (May 15, 2020): 58-71.

${ }^{25}$ Fathul Mujib and Nailur Rahmawati, Permainan Edukatif Pendukung Pembelajaran Bahasa Arab (Yogyakarta: Diva Press, 2012), 172.

${ }^{26}$ Ahmad Bukhori Muslim, Fuad Abdul Hamied, and Didi Sukyadi, "Integrative and Instrumental but Low Investment: The English Learning Motivation of Indonesian Senior High School Students," Indonesian Journal of Applied Linguistics 9, no. 3 (February 10, 2020): 493-507.

${ }^{27}$ Syamsuddin Asyrofi, Metode, Strategi, Dan Permainan Edukatif Dalam Pembelajaran Bahasa Arab (Yogyakarta: Aura Pustaka, 2014), 159. 
the method and to compare Arabic learning motivation of the experimental class and the control class in Arabic learning. It is hoped that students' Arabic learning motivation increase after application of Grammatical Hunting language educational game method and there are significant differences in the students' Arabic learning motivation between the experimental class and the control class. Theoretically, the research findings are assumed to give contribution to the wealth of knowledge or literature in the field of Arabic language education. Practically, the use of this method is expected to be able to create a pleasant learning atmosphere and can increase the student of class VIII MTsN 9 Bantul Yogyakarta Arabic learning motivation.

\section{Method}

This study used quantitative approach which needs the data in the form of numbers in data collection and analysis. The type of research used was experimental research designed in the form of quasi-experimental research aims to examine the causeeffect relationship by manipulating one or more variables in one or more experimental groups and comparing the results with a control group that did not experience manipulation. ${ }^{28}$ The form of research design that the researcher used in this quasiexperimental research was the non-equivalent group design because the research subjects were not determined randomly, either for the experimental group or the control group. ${ }^{29}$

To get a sample that represents the characteristics of the existing population and there is no bias in the results of the study, the researcher used non-probability sampling, a sampling technique that does not provide equal opportunities for all members of the population to become a sample. ${ }^{30}$ In this regard, the researcher used the purposive sampling type by choosing deliberately according to the research objectives. In this case, the sample of this study was VIII B grade of MTsN 9 Bantul Yogyakarta, totaling 31 students as the experimental class and VIII C grade of MTsN 9 Bantul Yogyakarta, totaling 29 students as the control class. The clases were determined by the same background, both from school origin, ${ }^{31,32}$ age, and gender. In addition, these two classes

28 Jalaludin Rahmat, Metode Penelitan Komunikasi Dilengkapi Contoh Analisis Statistik (Bandung: PT Remaja Rosdakarya, 2004), 32.

${ }_{29}$ Jalaludin Rahmat, 185.

${ }^{30}$ Purwanto, Statistik Untuk Penelitian (Yogyakarta: Pustaka Pelajar, 2011), 21.

31 Mukmin Mukmin, "The Effect Of Educational Background And Language Competence On Students' Arabic Language Motivation," Arabiyat: Jurnal Pendidikan Bahasa Arab dan Kebahasaaraban 6, no. 1 (June 12, 2019): 36-52. 
have the same conditions when viewed from the arrangement of classrooms and the duration of learning.

The data in this study were obtained from primary data and secondary data. Primary data from this study was Arabic language teachers and class VIII B and VIII C students whose results were obtained from data collection in the form of participant observation, semi-structured interviews, closed questionnaires, and documentation. The guidance of the data collection instruments had been validated by Zidni Imawan, S.Psi., M.Psi, a psychology lecturer of Sunan Kalijaga State Islamic University. Meanwhile, the secondary data were scientific works that are relevant to this research. The data regarding student' Arabic learning motivation before and after using Grammatical Hunting language educational game method were obtained from a closed questionnaire measured using a Likert scale and had passed the construct validity test and the reliability test with the cronbach alpha technique.

The data analysis in this study consisted of analysis by using descriptive statistics and independent-sample t-test with the help of SPSS 23. The researcher used quantitative descriptive methods using paired sample t-test to find out students' Arabic learning motivation after its implementation methods ${ }^{33}$ and independent-sample t-test to compare the motivation to learn Arabic between the experimental class and the control class. ${ }^{34}$ However, the researcher tested the normality and homogeneity test as a prerequisite for data analysis before the analysis was carried out.

$$
\begin{array}{cc}
\text { E } & \mathbf{O}_{1}-\mathrm{X}-\mathrm{O}_{2} \\
\mathrm{~K} & \mathrm{O}_{3}---\mathrm{O}_{4}
\end{array}
$$

Figure 1. Non Equivalent Control Group Design

Description

E : The experimental class

$\mathrm{K} \quad$ : The control class

O1 : The experimental class pre-test

${ }^{32}$ Nur Fuadi Rahman, "Motivasi Belajar Bahasa Arab (Studi Kasus Mahasiswa PBA IAIN Palangkaraya 2017/2018)," Jurnal Al Bayan: Jurnal Jurusan Pendidikan Bahasa Arab 10, no. 1 (June 7, 2018): 22-35.

${ }^{33}$ Jonathan Sarwono, Statistik Itu Mudah: Panduan Lengkap Untuk Belajar Komputasi Statistik Menggunakan SPSS16 (Yogyakarta: CV Andi Offset, 2009), 134.

${ }^{34}$ Nila Kesumawati, Allen Marga Retta, and Novita Sari, Pengantar Statistik Penelitian (Depok: Rajawali Pers, 2017). 
O2 : The experimental class post-test

O3 : The control class pre-test

$\mathrm{O} 2$ : The control class post-test

$\mathrm{X} \quad$ : The treatment (using Grammatical Hunting)

: No treatment (using lecture method)

\section{Result and Discussion}

Before conducting the research, the researcher prepared a questionnaire for student' Arabic learning motivation as follows: ${ }^{35}$

Table 1. Questionnaire Grid of Student’ Arabic Learning Motivation

\begin{tabular}{|c|c|c|c|c|c|}
\hline \multirow{2}{*}{ No. } & \multirow{2}{*}{ Aspect } & \multirow{2}{*}{ Indicator } & \multicolumn{2}{|c|}{ Item } & \multirow{2}{*}{$\begin{array}{c}\text { Number of } \\
\text { Item }\end{array}$} \\
\hline & & & + & - & \\
\hline \multirow[t]{2}{*}{1.} & $\begin{array}{l}\text { Persistence in doing } \\
\text { assignments }\end{array}$ & $\begin{array}{l}\text { Students show sincerity when } \\
\text { doing assignments. }\end{array}$ & 1,2 & 3,4 & \multirow[b]{2}{*}{8} \\
\hline & & $\begin{array}{l}\text { Students provide time outside } \\
\text { of class hours to do } \\
\text { assignments }\end{array}$ & 5,6 & 7,8 & \\
\hline \multirow[t]{2}{*}{2.} & $\begin{array}{l}\text { Resilience in the face } \\
\text { of difficulty }\end{array}$ & $\begin{array}{l}\text { Students show high fighting } \\
\text { power when faced with } \\
\text { difficulties. }\end{array}$ & 9,10 & 11,12 & \multirow[b]{2}{*}{8} \\
\hline & & $\begin{array}{l}\text { Students try to overcome the } \\
\text { difficulties they face. }\end{array}$ & 13,14 & 15,16 & \\
\hline \multirow[t]{2}{*}{3.} & $\begin{array}{l}\text { Showing interest in a } \\
\text { variety of issues }\end{array}$ & $\begin{array}{l}\text { Students are enthusiastic about } \\
\text { participating in the teaching } \\
\text { and learning process. }\end{array}$ & 17,18 & 19,20 & \multirow[b]{2}{*}{8} \\
\hline & & $\begin{array}{l}\text { Students pay attention to the } \\
\text { explanation given by the } \\
\text { teacher. }\end{array}$ & 21,22 & 23,24 & \\
\hline \multirow[t]{2}{*}{4.} & $\begin{array}{l}\text { Prefer to } \quad \text { study } \\
\text { independently }\end{array}$ & Students learn independently. & 25,26 & 27,28 & \multirow[b]{2}{*}{8} \\
\hline & & $\begin{array}{l}\text { Students do assignments } \\
\text { independently. }\end{array}$ & 29,30 & 31,32 & \\
\hline \multirow[t]{2}{*}{5.} & $\begin{array}{l}\text { Get bored with routine } \\
\text { tasks quickly }\end{array}$ & Students love the new things. & 33,34 & 35,36 & \multirow[b]{2}{*}{8} \\
\hline & & Students do creative activities. & 37,38 & 39,40 & \\
\hline \multirow[t]{2}{*}{6.} & Can defend his opinion & $\begin{array}{l}\text { Students can convey their } \\
\text { opinions. }\end{array}$ & 41,42 & 43,44 & \multirow[b]{2}{*}{8} \\
\hline & & $\begin{array}{l}\text { Students can defend their } \\
\text { opinion. }\end{array}$ & 45,46 & 47,48 & \\
\hline
\end{tabular}

${ }^{35}$ Sardiman, Interaksi Dan Motivasi Belajar Mengajar (Jakarta: Rajawali Pers, 1986), 82-83. 


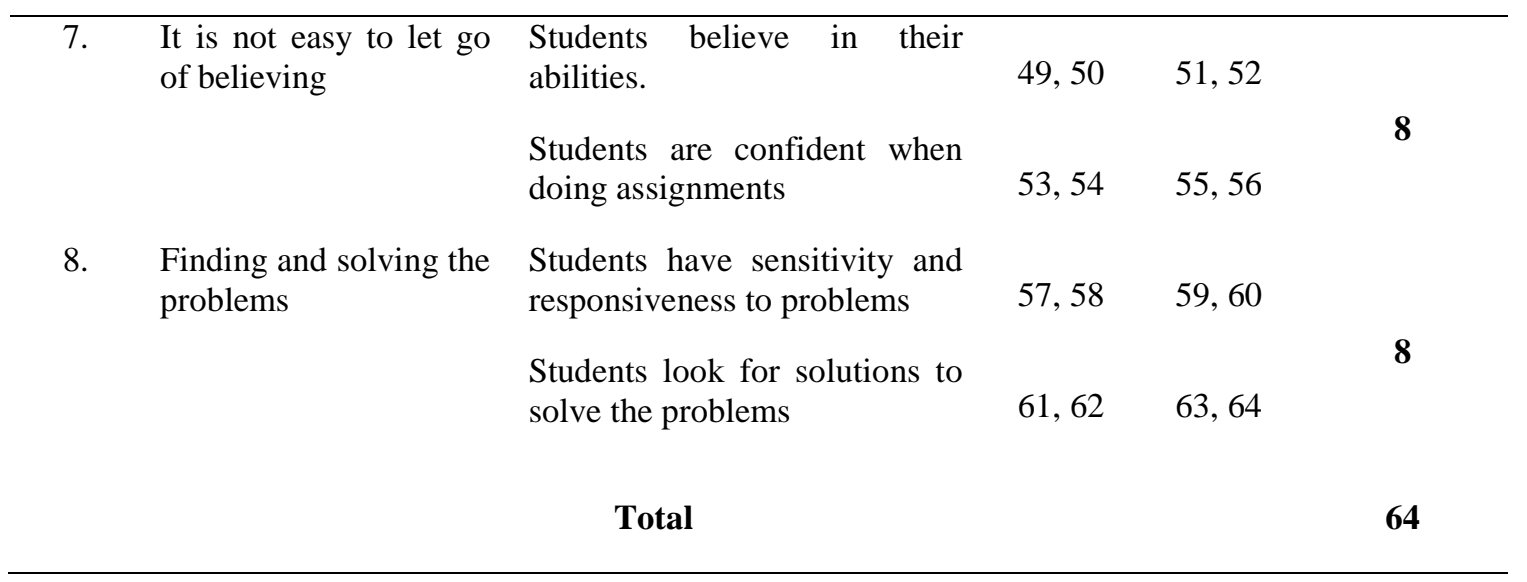

\section{Validity and Reliability Test}

After compiling a questionnaire consisting of 64 items, the researcher took the instrument testing through validity testing. The researcher conducted a validity test with experts showed that items $9,10,11,17,24,28,32,33,35,38,39,40,44,45,46,49,54$, and 64 must be corrected by using language operational ones to describe the indicators better. After making changes according to input from experts, all items in the questionnaire are following the indicators and declared valid to be used as data collection instruments. Furthermore, the researcher tested the questionnaire to determine the validity of each item with a total of 56 respondents.

The researcher used SPSS 23 program in testing the validity of the instrument with the product-moment correlation formula because the number of respondents was $\geq$ 30 people. $r_{\text {table }}$ for degrees of freedom of $54(\mathrm{df}=\mathrm{n}-2=56-2=54)$ with a significance level of $5 \%$ is 0.263 . This test is done by connecting the item score and the total score, then comparing the rcount value in the total score column with the $r_{\text {table }}$ value. Item is said to be valid if the value $r_{\text {count }} \geq r_{\text {table }}$ and declared invalid if the $r_{\text {count }}<r_{\text {tabel }}$ value. The data shows that the items totaling 64 items had been correlated with the total score of the answers given by students, so as many as 52 items with a value of $\geq 0.263$ and 12 items with a value of $<0.263$. So, it can be concluded that 52 items were declared valid and 12 items were declared invalid.

The next is the reliability of the instrument test carried out to determine the consistency or stability of the score of a research instrument against the same individual at different times. A reliable instrument is if the results shown by individuals are relatively the same after repeated trials. Researchers used Cronbach's alpha technique with SPSS 23 in measuring instrument reliability. The decision-making criterion is if the 
Cronbach's alpha value was $\geq 0.60$ then the questionnaire is declared reliable. However, if the Cronbach's alpha value $<0.60$, the questionnaire is declared unreliable. The result of the reliability test of the student's Arabic learning motivation is:

Tabel 2. The Reliability of The Instrument Result

\begin{tabular}{cc}
\hline \multicolumn{2}{c}{ Reliability Statistics } \\
\hline Cronbach's Alpha & N of Items \\
, 906 & 64 \\
\hline
\end{tabular}

From the table 2, it can be known that the Cronbach's alpha value is 0.906 , which was $\geq 0.60$. Thus, the students' Arabic learning motivation questionnaire was declared reliable and fit for the research instrument.

\section{Descriptive Statistic of Students' Arabic Learning Motivation}

\section{Experimental Class Arabic Learning Motivation}

The Arabic learning motivation in the experimental class, which in the learning process used the Grammatical Hunting language educational game method, is known after the researcher spreads a questionnaire in the form of a pre-questionnaire and a postquestionnaire to each sample in the experimental class which was 31 students. Then, the data was processed to obtain data about the motivation to learn Arabic.

Table 3. Descriptive Scale of Experimental Class Pre-questionnaire and Post-questionnaire

\begin{tabular}{|c|c|c|}
\hline \multirow{2}{*}{ Jumlah Siswa } & Pre-questionnaire & Post-questionnaire \\
\hline & 31 & 31 \\
\hline Maximum & 228 & 234 \\
\hline Minimum & 101 & 106 \\
\hline Mean & 152 & 176 \\
\hline Standard Deviation & 33 & 34 \\
\hline Gain & & \\
\hline
\end{tabular}

Table 3. shows the descriptive scale of the pre-questionnaire and the postquestionnaire of experimental class. There is an increase in the average pre-questionnaire and post-questionnaire scores for the experimental class, which was 23 . The maximum pre-questionnaire of experimental class was 228, then increased to 234 in the postquestionnaire. The minimum score of experimental class pre-questionnaire was 101, while the post-questionnaire score was 106 .

Furthermore, the data is presented in a pie chart below to make it more concise and easy to understand. The graph includes the following: 


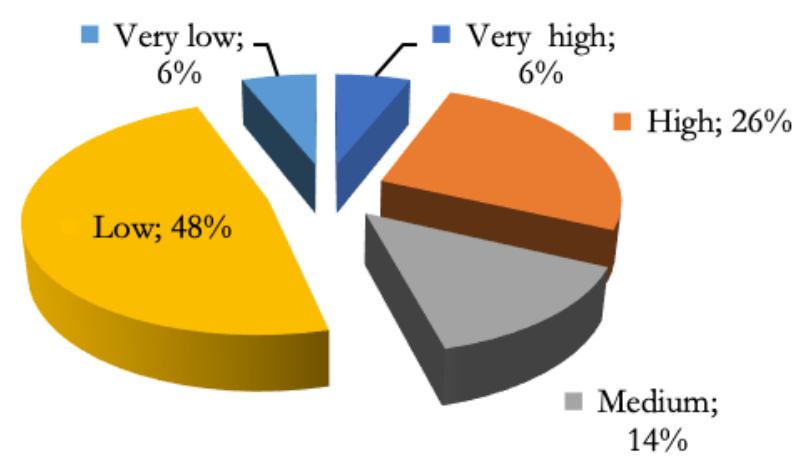

Figure 2. Result Percentage of Experimental Class Pre-questionnaire

Figure 2 illustrates the result percentage of experimental class pre-questionnaire before taking action. Most of the pre-questionnaire results were in the low category. $6 \%$ is in the very high category, $26 \%$ is in the high, $14 \%$ is in the medium category, and $48 \%$ is in a low, while $6 \%$ is in the very low.

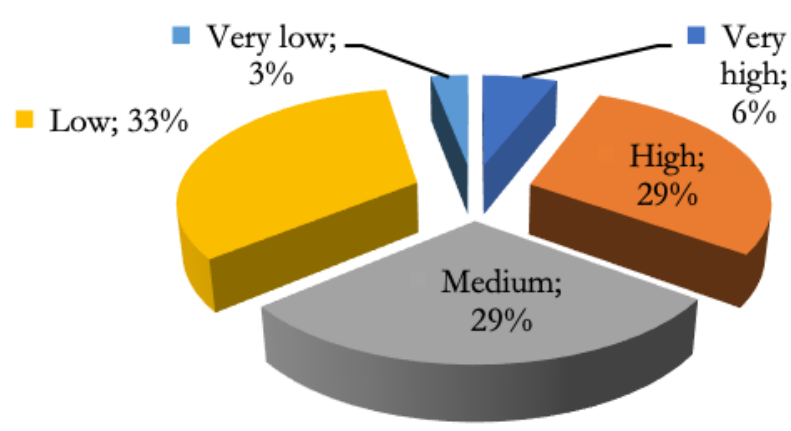

Figure 3. Result Percentage of Experimental Class Post-questionnaire

Figure 3. shows result percentage of experimental class post-kuisioner. The high and medium categories have the same percentage value, namely $29 \%$. As for $6 \%$ of students have very high Arabic learning motivation, 33\% of students are in a low, while $3 \%$ of students are in the very low.

Based on the data, we can conclude that experimental class Arabic learning motivation after the implementation of the Grammatical Hunting language educational game method has increased by $3 \%$ in the high level and $15 \%$ in the medium level, while the low level has decreased by $15 \%$ and in the very low level which has decreased of $3 \%$. 


\section{Control Class Arabic Learning Motivation}

The descriptive statistics of the data are as follows:

Table 4. Descriptive scale of Control Class Pre-questionnaire and Post-questionnaire

\begin{tabular}{lcc}
\hline \multirow{2}{*}{ Jumlah Siswa } & Pre-questionnaire & Post-questionnaire \\
\cline { 2 - 3 } & 29 & 29 \\
\hline Maximum & 210 & 227 \\
Minimum & 111 & 61 \\
Mean & 156 & 157 \\
Standard Deviation & 28 & 39 \\
Gain & & $\mathbf{1}$ \\
\hline
\end{tabular}

Table 4. shows the descriptive scale of the pre-questionnaire and the postquestionnaire of control class. The increase in the mean pre-questionnaire and postquestionnaire scores for the experimental class was 1. The maximum value for the control class pre-questionnaire was 210 and increased to 227 on the post-questionnaire. The minimum score for the pre-questionnaire of experimental class was 111 , while for the post-questionnaire was 61 .

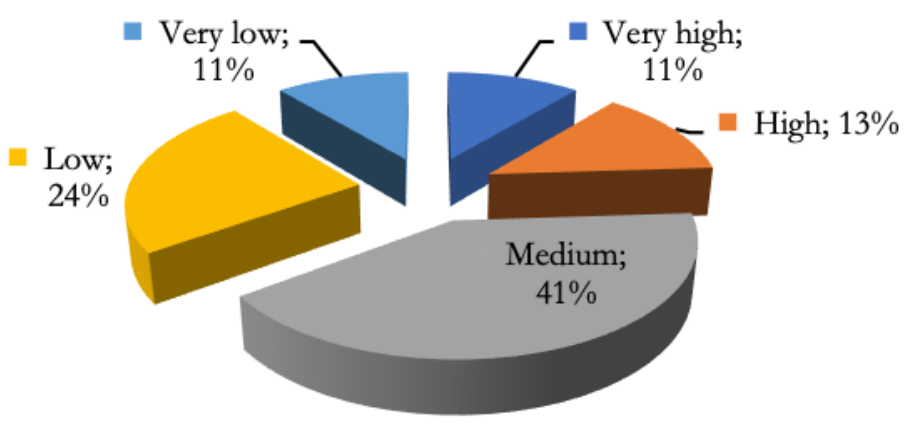

Figure 4. Result Percentage of Control Class Pre-questionnaire

Figure 4. illustrates that the result percentage of control class prequestionnaire. The largest percentage is in the medium category, namely $41 \%$. As for $11 \%$ in the very high category, $13 \%$ in the high level, $41 \%$ in the medium category, and $24 \%$ in the low level, while $11 \%$ were in the very low level. 


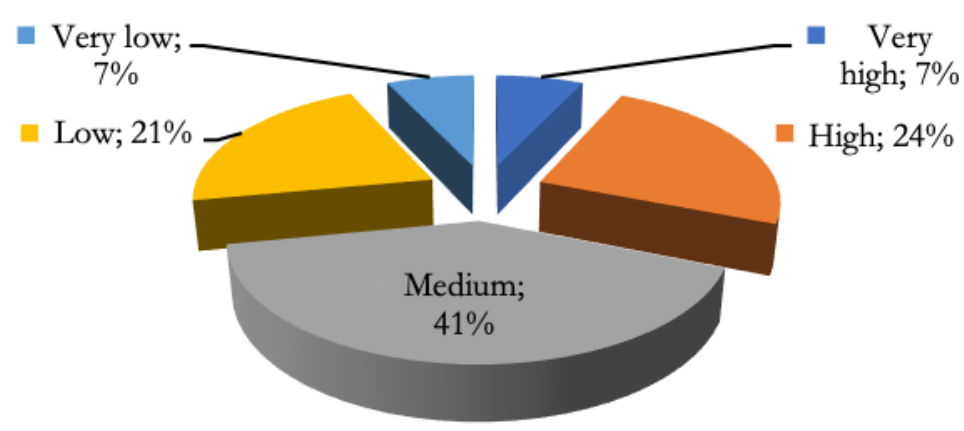

Figure 5. Result Percentage of Control Class Post-questionnaire

Figure 5. illustrates the result percentage of control class post-questionnaire. The highest score was in the medium category which was $41 \%$. As for $7 \%$ of control class students had very high Arabic learning motivation, 24\% of students were in the high level, and $21 \%$ of students were in a low level, while $7 \%$ of students were in the very low level. Based on the data, we can conclude that control class Arabic learning motivation after the implementation of the lecture method had increased by $11 \%$ in the high level and had decreased in the very high level by $4 \%$, in the low level by $3 \%$, and in the very low level $3 \%$.

The gain of Experimental Class and Control Class Arabic learning motivation can be seen in the following table:

Tabel 5. Students' Arabic Learning Motivation Gain

\begin{tabular}{cc}
\hline Class & Gain \\
\hline Experiment & 23 \\
Control & 1 \\
\hline
\end{tabular}

Based on the table 5. we know that students Arabic learning motivation gain the mean increase in the experimental class is higher than the increase in the mean of the control class. It shows that the application of Grammatical Hunting language educational game method can increase students' Arabic learning motivation compared to the learning process that does not apply Grammatical Hunting language educational game method (lecture method). 


\section{The Differences of Experimental Class and Control Class Arabic Learning Motivation}

After the $\mathrm{H}_{0}$ of the normality test and homogeneity test is accepted, the next step is to analyze the data by using the t-test. The type of t-test used is the paired sample t-test to find out students' Arabic learning motivation before and after by using SPSS 23.

Table 6. Paired Sample T-test Result of Experiment Class

\begin{tabular}{ccccccl}
\hline No. & Data & Mean & $\mathbf{t}_{\text {count }}$ & $\mathbf{t}_{\text {table }}$ & $\begin{array}{c}\text { Sig. } \\
(\mathbf{2} \text { tailed })\end{array}$ & Description \\
\hline 1. & Pre-questionnaire & 152,48 & $-6,924$ & 2,042 & 0,000 & Significant \\
\hline 2. & Post-questionnaire & 175,71 & & & \\
\hline
\end{tabular}

Table 6. shows the paired sample t-test result of experimental class. The postquestionnaire mean of the experimental class is higher than the pre-questionnaire mean. Besides, the sig. (2-tailed) value was 0,000 proves that sig. (2-tailed) $<0.05$. Therefore, it can be concluded that $\mathrm{H}_{0}$ is rejected and $\mathrm{H}_{\mathrm{a}}$ is accepted. It shows that there is a significant difference in motivation to learn Arabic between before and after the implementation of the Grammatical Hunting method, meaning that students' Arabic learning motivation increases after the implementation of the Grammatical Hunting of language educational game method.

Table 7. Paired Sample T-test Result of Control Class

\begin{tabular}{ccccccc}
\hline No. & Data & Mean & $\mathbf{t}_{\text {count }}$ & $\mathbf{t}_{\text {table }}$ & $\begin{array}{c}\text { Sig. } \\
(\mathbf{2} \text { tailed })\end{array}$ & Description \\
\hline 1. & Pre-questionnaire & 156,07 & $-0,107$ & 2,048 & 0,916 & Insignificant \\
\hline
\end{tabular}

Table 7. shows the paired sample t-test result of control class. The postquestionnaire mean of the control class is not higher than the pre-questionnaire mean. In addition, sig.(2-tailed) value was 0.916 which proves that the sig. (2-tailed) $>0.05$. Therefore, it can be concluded that $\mathrm{H}_{0}$ is accepted and $\mathrm{H}_{\mathrm{a}}$ is rejected. This shows that there is no significant difference in Arabic learning motivation between before and after the application of the lecture method.

It is known that there is a significant difference in Arabic learning motivation between the experiment class which applied Grammatical Hunting language educational game method and the control class which did not apply Grammatical Hunting language educational game method.

Beside, in this research was not only using paired sample t-test to analyze the $\underline{\text { data, but also using the independent sample t-test to compare the differences of }}$ Jurnal Al Bayan: Jurnal Jurusan Pendidikan Bahasa Arab, 13 (1): 149-166 (2021)| 160 
experimental class for Arabic learning motivation after applying Grammatical Hunting language educational game method and the control class which did not apply the same game method in the learning process.

Table 8. Independent Sample T-test Result of Pre-questionnaire Score

\begin{tabular}{llccccc}
\hline No. & \multicolumn{1}{c}{ Data } & Mean & $\mathbf{t}_{\text {count }}$ & $\mathbf{t}_{\text {table }}$ & $\begin{array}{c}\text { Sig. } \\
(\mathbf{2} \text { tailed })\end{array}$ & Description \\
\hline 1. & Pre-experiment & 152,48 & $-0,453$ & 2,001 & 0,652 & Insignificant \\
\hline 2. & Pre-control & 156,66 & $-0,456$ & 2,001 & 0,650 & \\
\hline
\end{tabular}

Table 8. shows the independent sample t-test between experiment class and control class pre-questionnaire and post-questionnaire scores. There is no significant difference between the mean of two classes. The pre-questionnaire $t_{\text {count }}$ for the experimental class was $-0.453\left(\mathrm{t}_{\text {count }}=-0.453\right)$ and the pre-questionnaire for the control class was $-0.456\left(\mathrm{t}_{\text {count }}=-0.456\right)$ and the $\mathrm{t}_{\text {table }}$ was $2.001\left(\mathrm{t}_{\text {table }}=2.001\right)$ with as many degrees of freedom as $58(\mathrm{df}=58)$. These results prove that tcount $<\mathrm{t}_{\text {table }}$, namely -0.453 $<2.001$ and $-0.456<2.001$. Therefore, it can be concluded that $\mathrm{H}_{0}$ is accepted, meaning that $\mathrm{H}_{\mathrm{a}}$ is rejected.

Tabel 9. Independent Sample T-test Result of Post-questionnaire Score

\begin{tabular}{lllcccl}
\hline No. & \multicolumn{1}{c}{ Data } & Mean & $\mathbf{t}_{\text {count }}$ & $\mathbf{t}_{\text {table }}$ & $\begin{array}{c}\text { Sig. } \\
(\mathbf{2} \text { tailed })\end{array}$ & Description \\
\hline 1. & Post-experiment & 175,71 & 2,042 & 2,001 & 0,049 & Significant \\
2. & Post-control & 156,66 & 2,006 & 2,001 & 0,050 & \\
\hline
\end{tabular}

Table 9. shows the independent sample t-test result of post-questionnaire score. There is a significant difference between the mean of the two classes. The experimental class post-questionnaire $\mathrm{t}_{\text {count }}$ was $2,042\left(\mathrm{t}_{\text {count }}=2,042\right)$ and the control class postquestionnaire was 2,006 $\left(\mathrm{t}_{\text {count }}=2,006\right)$, while the $\mathrm{t}_{\text {-table }}$ was 2,001 with 58 degrees of freedom $(\mathrm{df}=58)$. These results prove that $\mathrm{t}_{\text {count }} \geq \mathrm{t}_{\text {table, }}$, namely $2.042 \geq 2.001$ and 2.006 $\geq 2.001$. Therefore, it can be concluded that $\mathrm{H}_{\mathrm{a}}$ is accepted, meaning that $\mathrm{H}_{0}$ is rejected. Thus, it can be concluded that there is a significant difference in the experimental class Arabic learning motivation who apply Grammatical Hunting language educational game method and the control class who does not apply Grammatical Hunting language educational game method.

Qawa'id learning will be more effective if it is supported by several components, including the teacher. ${ }^{36}$ As the most important factor in the teaching and learning

${ }^{36}$ Fathul Maujud and Cipta Ningsih, "Dauru Ta'lim Qawaid al-Lughah al-Arabiyah Fi Bina'i Maharat al-Qira'ah Li al-Tullab al-Faslh al-Awwal Fi Madrasah Hikmah al-Syarif al-Aliyah Nahdlah al161 | Jurnal Al Bayan: Jurnal Jurusan Pendidikan Bahasa Arab, 13 (1): 149-166 (2021) 
process,${ }^{37}$ teachers are required to choose methods that are appropriate and have an effect on student learning success, ${ }^{38}$ as Grammatical Hunting educational game method applied to qawa'id learning in this experimental class. The results showed a significant difference when compared with the increase in motivation to learn Arabic in the control class. So, Grammatical Hunting language educational game method affects in increasing students' motivation to learn Arabic.

This research is in line with previous research which shows that language games can motivate students to learn qawa' $i d .{ }^{39}$ This is because language games can make the learning process more enjoyable, eliminates boredom, ${ }^{40}$ and creates cooperation, and healthy competition between students. ${ }^{41}$ In addition, language games can affect the cognitive aspects of students ${ }^{42}$ where students will find it easier to understand and memorize the material. ${ }^{43}$ However, it should be noted that language games have the obstaclesnif the class conditions would be crowded. Therefore, as one of an essential factors in the learning process, ${ }^{44}$ teachers are required to be active in guiding students. ${ }^{45}$

\section{Conclusion}

Grammatical Hunting language educational game method can affect in increasing students' grade of VIII MTsN 9 Bantul Yogyakarta Arabic learning motivation. In

Wathan Salut Narmada Lombok Barat Nusa Tenggara Barat," Arabiyatuna: Jurnal Bahasa Arab 3, no. 1 (May 14, 2019): 65-92.

37 Anwar Sanusi, Sofyan Sauri, and Yayan Nurbayan."Non-Native Arabic Language Teacher: Low Teacher's Professional Competence Low Quality Outcomes?."Arabiyat: Jurnal Pendidikan Bahasa Arab dan Kebahasaaraban 7, no. 1 (2020): 45-60.

${ }^{38}$ Rohmatul Faizah, "Implementing the Meth od of Memorizing Vocabulary in Pushing Students to Learn Arabic," Langkawi: Journal of The Association for Arabic and English 4, no. 1 (June 8, 2018): $65-70$.

${ }^{39}$ Muassomah and Munjiah, "Learning Qawaid Through Language Game Adlif Kalimatan for Students of Arabic Language and Literature at UIN Maulana Malik Ibrahim Malang."

${ }^{40}$ Uliyah and Isnawati, "Metode Permainan Edukatif Dalam Pembelajaran Bahasa Arab."

${ }^{41}$ Zaimatuz Zakiyah and Nurul Huda, "Implementasi Metode Permainan Bahasa Grammatical Hunting Dalam Pembelajaran Bahasa Arab Di Kelas 3/1 Mutawasith Khoiriyah Wittaya Mulnithi Betong, Yala, Thailand Tahun Ajaran 2019/2020," Jurnal Alfazuna: Jurnal Pembelajaran Bahasa Arab dan Kebahasaaraban 4, no. 2 (July 20, 2020): 212-226.

42 Mostafa Papi, "Motivation As Quality: Regulatory Fit Effects On Incidental Vocabulary Learning," Studies in Second Language Acquisition 40, no. 4 (December 2018): 707-730.

43 Arif Humaini, "Experimental Research: The Effectiveness of Card Game Learning Media in Learning Shorof," Jurnal Al Bayan: Jurnal Jurusan Pendidikan Bahasa Arab 10, no. 2 (December 20, 2018): 295-307.

${ }^{44}$ Rahmi Fhonna and Yunisrina Qismullah Yusuf, "Indonesian Language Learning Methods in Australian Elementary Schools," Journal of Language and Education 6, no. 2 (June 30, 2020): 106-119.

45 Eunseok Ro and Alfred Rue Burch, "Willingness to Communicate/Participate' in Action: A Case Study of Changes in a Recipient's Practices in an L2 Book Club," Linguistics and Education 58 (August 1, 2020): 100821. 
addition, there was a significant difference between experimental class Arabic learning motivation which used Grammatical Hunting language educational game method and control group which did not use Grammatical Hunting language educational game method. The Arabic teacher is suggested to use this method in qawa' 'id learning because it can create an enjoyable learning atmosphere and can increase the students Arabic learning motivation. This research did not measure the effect of Grammatical Hunting towards students' achievement and the effectiveness of this method in qawa'id learning due to limited learning time allocation. Therefore, future research is suggested to examine this method in qawa'id learning to find out the effect of this method towards students' achievement and its effectiveness.

\section{Acknowledgment}

The authors would like to sincerely thank to Arabic Education Study Program, Sunan Kalijaga State Islamic University of Yogyakarta for supporting this research, to Zidni Imawan, S.Psi., M.Psi, a psychology lecturer of Sunan Kalijaga State Islamic University as the questionnaire validator of this research, and to the editor and the reviewers who helped the authors in accomplishing this paper.

\section{References}

Abdurrahman, Maman, A. Suherman, Masor Masor, and Asep M. Irfan Fadhlillah. "Tantangan Guru Bahasa Arab Madrasah Aliyah Dalam Perspektif Kompetensi Pedagogik Dan Profesional." Arabiyat: Jurnal Pendidikan Bahasa Arab dan Kebahasaaraban 2, no. 1 (July 1, 2015): 43-58.

Adilah, Nida. "Perbedaan Hasil Belajar IPA melalui Penerapan Metode Mind Map dengan Metode Ceramah." Indonesian Journal of Primary Education 1, no. 1 (June 17, 2017): 98-103.

Al-Ghulayaini, Syaikh Musthafa. Jāmi 'u Ad-Durūs al-'Arabiyah. Beirut-Lebanon: Darul Bayan, 2008.

Asy'ari, M. Asy'ari M. "Method Of Nahwu In Arabic Learning.” لسـانـا (LISANUNA): Jurnal Ilmu Bahasa Arab dan Pembelajarannya 10, no. 1 (August 27, 2020): 7092.

Asyrofi, Syamsuddin. Metode, Strategi, Dan Permainan Edukatif Dalam Pembelajaran Bahasa Arab. Yogyakarta: Aura Pustaka, 2014.

Djamarah, Syaiful Bahri. Psikologi Pendidikan. Jakarta: Rineka Cipta, 2011. 
Ehsan, Namaziandost, Shatalebi Vida, and Nasri Mehdi."The Impact of Cooperative Learning on Developing Speaking Ability and Motivation Toward Learning English". Journal of Language and Education. 5, no. 3 (19) (2019).

Faizah, Rohmatul. "Implementing the Method of Memorizing Vocabulary in Pushing Students to Learn Arabic." Langkawi: Journal of The Association for Arabic and English 4, no. 1 (June 8, 2018): 65-70.

Fhonna, Rahmi, and Yunisrina Qismullah Yusuf. "Indonesian Language Learning Methods in Australian Elementary Schools." Journal of Language and Education 6, no. 2 (June 30, 2020): 106-119.

Hilmi, Danial. “Ta'lim Al-Qawa'id Al-Nahwiyah 'Ala Asas Madkhal Al-Tanwim AlMaghnathisi." Arabi: Journal of Arabic Studies 2, no. 1 (August 6, 2017): 54-66.

Huda, Mokhammad Miftakhul, Pandi Rais, Agus Miftakhus Surur, and Ati' Rohmawati. "Improvement Of Nahwu And Sharaf Learning Using Amtsilati Method." Ijaz Arabi Journal of Arabic Learning 3, no. 1 (April 5, 2020). Accessed November 15, 2020. http://ejournal.uin-malang.ac.id/index.php/ijazarabi/article/view/6781.

Humaini, Arif. "Experimental Research: The Effectiveness of Card Game Learning Media in Learning Shorof." Jurnal Al Bayan: Jurnal Jurusan Pendidikan Bahasa Arab 10, no. 2 (December 20, 2018): 295-307.

In'ami, Moh, and Putri Zunita Shara. "Wasilah al Lu'bah al Lughowiyah Broken Square Wa Snow Balling Fii Ta'lim al Lughoh al 'Arabiyyah Li Tarqiyah Maharoh al Qiroah." Jurnal Al Bayan: Jurnal Jurusan Pendidikan Bahasa Arab 10, no. 2 (December 20, 2018): 224-239.

Islam, Asep Muhammad Saepul. "Faktor Demotivasi Pembelajaran Bahasa Arab Dalam Perspektif Siswa Madrasah." Arabiyat: Jurnal Pendidikan Bahasa Arab dan Kebahasaaraban 2, no. 1 (July 1, 2015): 1-16.

Kesumawati, Nila, Allen Marga Retta, and Novita Sari. Pengantar Statistik Penelitian. Depok: Rajawali Pers, 2017.

Latuconsina, Sarah N. "Efektivitas Permainan Bahasa Arab Dalam Meningkatkan Kemampuan Membaca Mahasiswa Program Studi Pendidikan Bahasa Arab." Arabi : Journal of Arabic Studies 3, no. 2 (December 31, 2018): 145-156.

Maujud, Fathul, and Cipta Ningsih. "Dauru Ta'lim Qawaid al-Lughah al-Arabiyah Fi Bina'i Maharat al-Qira'ah Li al-Tullab al-Faslh al-Awwal Fi Madrasah Hikmah alSyarif al-Aliyah Nahdlah al-Wathan Salut Narmada Lombok Barat Nusa Tenggara Barat.” Arabiyatuna: Jurnal Bahasa Arab 3, no. 1 (May 14, 2019): 65-92.

Muassomah, Muassomah, and Ma'rifatul Munjiah. "Learning Qawaid Through Language Game Adlif Kalimatan for Students of Arabic Language and Literature at UIN Maulana Malik Ibrahim Malang." ALSINATUNA 5, no. 1 (May 15, 2020): 58-71. 
Mujib, Fathul, and Nailur Rahmawati. Permainan Edukatif Pendukung Pembelajaran Bahasa Arab. Yogyakarta: Diva Press, 2012.

Mukmin, Mukmin. "The Effect Of Educational Background And Language Competence On Students' Arabic Language Motivation." Arabiyat : Jurnal Pendidikan Bahasa Arab dan Kebahasaaraban 6, no. 1 (June 12, 2019): 36-52.

Muslim, Ahmad Bukhori, Fuad Abdul Hamied, and Didi Sukyadi. "Integrative and Instrumental but Low Investment: The English Learning Motivation of Indonesian Senior High School Students." Indonesian Journal of Applied Linguistics 9, no. 3 (February 10, 2020): 493-507.

Oxford, Rebecca, and Jill Shearin. "Language Learning Motivation: Expanding the Theoretical Framework.” The Modern Language Journal 78, no. 1 (1994): 12-28.

Papi, Mostafa. "Motivation As Quality: Regulatory Fit Effects On Incidental Vocabulary Learning." Studies in Second Language Acquisition 40, no. 4 (December 2018): 707-730.

Pawlak, Mirosław. "Grammar Learning Strategies as a Key to Mastering Second Language Grammar: A Research Agenda." Language Teaching 53, no. 3 (July 2020): 358-370.

Prasad, Pabbuleti. "Language Games - A Games Better Method of Learning Vocabularies." 338-341. IJREAM: International Journal for Research in Engineering Application \& Management, n.d.

Purwanto. Statistik Untuk Penelitian. Yogyakarta: Pustaka Pelajar, 2011.

Rahman, Nur Fuadi. "Motivasi Belajar Bahasa Arab (Studi Kasus Mahasiswa PBA IAIN Palangkaraya 2017/2018)." Jurnal Al Bayan: Jurnal Jurusan Pendidikan Bahasa Arab 10, no. 1 (June 7, 2018): 22-35.

Rahmat, Jalaludin. Metode Penelitan Komunikasi Dilengkapi Contoh Analisis Statistik. Bandung: PT Remaja Rosdakarya, 2004.

Ridlo, Ubaid. "Model Pembelajaran Bahasa Arab Materi Al-Qawa'id al-Nahwiyyah." AlMa 'rifah: Jurnal Budaya, Bahasa, dan Sastra Arab 12, no. 2 (October 2, 2015): 46-57.

Rini, Rini. "Ushul al-Nahwi al-Arabi: Kajian Tentang Landasan Ilmu Nahwu." Arabiyatuna: Jurnal Bahasa Arab 3, no. 1 (May 14, 2019): 145-162.

Ro, Eunseok, and Alfred Rue Burch. "Willingness to Communicate/Participate' in Action: A Case Study of Changes in a Recipient's Practices in an L2 Book Club." Linguistics and Education 58 (August 1, 2020): 100821.

Rusady, Achmad Tito. “ Izdihar : Journal of Arabic Language Teaching, Linguistics, and Literature 1, no. 1 (September 7, 2018): 65-78. 
Sanusi, Anwar, Sofyan Sauri, and Yayan Nurbayan."Non-Native Arabic Language Teacher: Low Teacher's Professional Competence Low Quality Outcomes?" Arabiyat: Jurnal Pendidikan Bahasa Arab Dan Kebahasaaraban 7, no. 1 (2020): 45-60.

Sardiman. Interaksi Dan Motivasi Belajar Mengajar. Jakarta: Rajawali Pers, 1986.

Sarwono, Jonathan. Statistik Itu Mudah: Panduan Lengkap Untuk Belajar Komputasi Statistik Menggunakan SPSS16. Yogyakarta: CV Andi Offset, 2009.

Subekti, Adaninggar Septi. "L2 Motivational Self System and L2 Achievement: A Study of Indonesian EAP Learners". Indonesian Journal of Applied Linguistics 8, no. 1 (2018): 57-67.

Sulistianingsih, Endang, Rizka Febriani, and Jcs Pradjarto. "The Effect of Interactive Board Games (IBG) on Vocabulary Achievement." Langkawi: Journal of The Association for Arabic and English 5, no. 2 (December 27, 2019): 127-139.

Uliyah, Asnul, and Zakiyah Isnawati. "Metode Permainan Edukatif Dalam Pembelajaran Bahasa Arab." Shaut al Arabiyyah 7, no. 1 (June 27, 2019): 31-43.

Widodo, Arif. "Al-Lu'bah al-Lughawiyyah al-Namudzajiyyah Fi Ta'lim al-Kitabah." Jurnal Al Bayan: Jurnal Jurusan Pendidikan Bahasa Arab 11, no. 1 (June 1, 2019): 111-132.

Zakiyah, Zaimatuz, and Nurul Huda. "Implementasi Metode Permainan Bahasa Grammatical Hunting Dalam Pembelajaran Bahasa Arab Di Kelas 3/1 Mutawasith Khoiriyah Wittaya Mulnithi Betong, Yala, Thailand Tahun Ajaran 2019/2020." Jurnal Alfazuna: Jurnal Pembelajaran Bahasa Arab dan Kebahasaaraban 4, no. 2 (July 20, 2020): 212-226.

Zubaidi, Ahmad. "Development Of Mahârah Al-Istimâ' Test Instrument For Electronic Based Arabic Student Using The Kahoot! Application." Arabiyat: Jurnal Pendidikan Bahasa Arab dan Kebahasaaraban 7, no. 1 (June 4, 2020): 61-77.

"Peraturan Menteri Agama Republik Indonesia No. 000912 Tentang Kurikulum Madrasah 2013 Mata Pelajaran Pendidikan Agama Islam Dan Bahasa Arab,” 2013. 